\title{
GENERALIZATIONS OF CONVERSE JENSEN'S INEQUALITY AND RELATED RESULTS
}

\author{
S. IVELIĆ AND J. PEČARIĆ
}

Abstract. In this paper we prove generalizations of Converse Jensen's inequality for convex functions defined on convex hulls. As consequences we get generalizations of the HermiteHadamard inequality for convex functions defined on $k$-simplices in $\mathbb{R}^{k}$. We also present some related results which generalize results in [8].

Mathematics subject classification (2010): 26D15.

Keywords and phrases: Jensen's inequality, Converse Jensen's inequality, convex hull, convex functions, Hermite-Hadamard inequality, $k$-simplex, barycentric coordinates.

\section{REFERENCES}

[1] M. Bessenyei, The Hermite-Hadamard inequality on Simplices, Amer. Math. Monthly, 115, 4 (2008), 339-345.

[2] B. Gavrea, J. JakšEtić And J. PeČArić, On a global upper bound for Jessen's inequality, The Australian \& New Zeland Industrial and Applied Mathematics Journal, 50 (2009), 246-257.

[3] W. S. Cheung, A. Matković And J. PeČArić, A variant of Jessen's inequality and generalized means, J. Ineq. Pure and Appl. Math., 7, 1 (2006).

[4] A. Florea AND C. P. Niculescu, A Hermite-Hadamard inequality for convex-concave symmetric functions, Bull. Math. Soc. Sci. Math. Roumanie Tome, 50, 98 (2007), 149-156.

[5] A. Guess AB, G. Schmeisser, A Definiteness Theory for Cubature Formulae of Order Two, Constructive Approximation, 24, 4 (2006), 263-288.

[6] A. Guessab, G. SCHMeisser, Construction of positive definite cubature formulae and approximation of functions via Voronoi tessellations, Advances in Computational Mathematics, 32, 4 (2010), $25-41$.

[7] A. Guessab, G. Schmeisser, Negative Definite Cubature Formulae, Extremality and Delaunay Triangulation, Constructive Approximation, 31, 4 (2010), 95-113.

[8] A. MATKOVIĆ, J. PEČARIĆ, A variant of Jensen's inequality for convex functions of several variables, J. Math. Ineq., 1, 1 (2007), 45-51.

[9] E. J. McShane, Jensen's inequality, Bull. Amer. Math. Soc., 43 (1937), 521-527.

[10] D. S. Mitrinović, J. PeČArić And A. M. FinK, Classical and new inequalities in analysis, Kluwer Academic Publishers, The Netherlands, 1993.

[11] C. P. NiculESCU, The Hermite-Hadamard inequality for convex functions of a vector variable, Math. Ineq. Appl., 5 (2002).

[12] C. P. NICULESCU, The Hermite-Hadamard inequality for convex functions on a global NPC space, J. Math. Anal. Appl., 356 (2009).

[13] C. P. Niculescu AND L.-E. Persson, Old and new on the Hermite-Hadamard inequality, Real Analysis Exchange, 29, 2 (2003/2004), 663-685.

[14] J. E. PeČarić, F. Proschan, Y. L. Tong, Convex Functions, Partial Orderings, and Statistical Applications, Academic Press, New York, 1992.

[15] S. Simić, On a converse of Jensen's discrete inequality, J. Inequal. and Appl., 2009 (2009), Article ID 153080, 6 pages.

[16] S. Simić, On a new converse of Jensen's inequaity, Pub. De L'Instit. Mathem., 85, 99 (2009), 107110. 
[17] S. Simić, On an upper bound for Jensen's inequality, J. Inequal. Pure Appl. Math., 10, 2 (2009), Art. 60.

[18] D. M. Y. Sommerville, An Introduction to the Geometry of N Dimensions, Reprinted by Dover Press (1958).

[19] T. TRIF, Characterizations of convex functions of a vector variable via Hermite-Hadamard's inequality, J. Math. Ineq., 2, 1 (2008), 37-44.

[20] S. WA̧SOWICZ, Hermite-Hadamard-type inequalities in the aproximate integration, Math. Ineq. Appl., 11 (2008), 693-700. 